\title{
Extreme 15N Depletion in Seagrasses
}

Walton, Mark; Al-Maslamani, I.; Haddaway, Neal; Kennedy, Hilary; Castillo, A. ; Al-Ansari, E. S.; Al-Shaikh, I.; Abdel-Moati, M. ; Al-Yafei, M. A. A.; Le Vay, Lewis

\section{Estuaries and Coasts}

\author{
DOI: \\ 10.1007/s12237-016-0103-3
}

Published: 01/11/2016

Publisher's PDF, also known as Version of record

Cyswllt i'r cyhoeddiad / Link to publication

Dyfyniad o'r fersiwn a gyhoeddwyd / Citation for published version (APA):

Walton, M., Al-Maslamani, I., Haddaway, N., Kennedy, H., Castillo, A., Al-Ansari, E. S., AlShaikh, I., Abdel-Moati, M., Al-Yafei, M. A. A., \& Le Vay, L. (2016). Extreme 15N Depletion in Seagrasses. Estuaries and Coasts, 39(6), 1709-1723. https://doi.org/10.1007/s12237-016-01033

\footnotetext{
Hawliau Cyffredinol / General rights

Copyright and moral rights for the publications made accessible in the public portal are retained by the authors and/or other copyright owners and it is a condition of accessing publications that users recognise and abide by the legal requirements associated with these rights.

- Users may download and print one copy of any publication from the public portal for the purpose of private study or research.

- You may not further distribute the material or use it for any profit-making activity or commercial gain

- You may freely distribute the URL identifying the publication in the public portal ?
}

Take down policy

If you believe that this document breaches copyright please contact us providing details, and we will remove access to the work immediately and investigate your claim. 


\title{
Extreme ${ }^{15} \mathbf{N}$ Depletion in Seagrasses
}

\author{
M. E. M. Walton ${ }^{1} \cdot$ I. Al-Maslamani ${ }^{2} \cdot$ N. Haddaway ${ }^{1,3} \cdot$ H. Kennedy ${ }^{4} \cdot$ A. Castillo $^{2}$ • \\ E. S. Al-Ansari ${ }^{2}$ - I. Al-Shaikh ${ }^{2}$ M. Abdel-Moati ${ }^{5}$ M. A. A. Al-Yafei ${ }^{2}$ L. Le Vay ${ }^{1}$
}

Received: 16 October 2015 / Revised: 25 April 2016/Accepted: 27 April 2016

(C) The Author(s) 2016. This article is published with open access at Springerlink.com

\begin{abstract}
Seagrass beds form an important part of the coastal ecosystem in many parts of the world but are very sensitive to anthropogenic nutrient increases. In the last decades, stable isotopes have been used as tracers of anthropogenic nutrient sources and to distinguish these impacts from natural environmental change, as well as in the identification of food sources in isotopic food web reconstruction. Thus, it is important to establish the extent of natural variations on the stable isotope composition of seagrass, validating their ability to act as both tracers of nutrients and food sources. Around the world, depending on the seagrass species and ecosystem, values of seagrass $\mathrm{N}$ normally vary from 0 to $8 \% \delta^{15} \mathrm{~N}$. In this study, highly unusual seagrass $\mathrm{N}$ isotope values were observed on the east coast of Qatar, with significant spatial variation over a scale of a few metres, and with $\delta^{15} \mathrm{~N}$ values ranging from
\end{abstract}

Communicated by:Dennis Swaney

Electronic supplementary material The online version of this article (doi:10.1007/s12237-016-0103-3) contains supplementary material, which is available to authorized users.

M. E. M. Walton

m.walton@bangor.ac.uk

1 Centre for Applied Marine Sciences, College of Natural Sciences, Bangor University, Menai Bridge, Anglesey LL59 5EY, UK

2 Environmental Science Center, Qatar University, PO Box 2713, Doha, Qatar

3 MISTRA EviEM, Royal Swedish Academy of Sciences, Stockholm SE11418, Sweden

4 School of Ocean Sciences, College of Natural Sciences, Bangor University, Menai Bridge, Anglesey LL59 5EY, UK

5 Environmental Assessment Department, Ministry of Environment, PO Box 39320, Doha, Qatar
+2.95 to $-12.39 \%$ within a single bay during March 2012 . This pattern of variation was consistent over a period of a year although there was a seasonal effect on the seagrass $\delta^{15} \mathrm{~N}$ values. Seagrass, water column and sediment nutrient profiles were not correlated with seagrass $\delta^{15} \mathrm{~N}$ values and neither were longer-term indicators of nutrient limitation such as seagrass biomass and height. Sediment $\delta^{15} \mathrm{~N}$ values were correlated with Halodule uninervis $\delta^{15} \mathrm{~N}$ values and this, together with the small spatial scale of variation, suggest that localised sediment processes may be responsible for the extreme isotopic values. Consistent differences in sediment to plant ${ }^{15} \mathrm{~N}$ discrimination between seagrass species also suggest that species-specific nutrient uptake mechanisms contribute to the observed $\delta^{15} \mathrm{~N}$ values. This study reports some of the most extreme, negative $\delta^{15} \mathrm{~N}$ values ever noted for seagrass (as low as $-12.4 \%$ ) and some of the most highly spatially variable (values varied over $15.4 \%$ in a relatively small area of only $655 \mathrm{ha}$ ). These results are widely relevant, as they demonstrate the need for adequate spatial and temporal sampling when working with $\mathrm{N}$ stable isotopes to identify food sources in food web studies or as tracers of anthropogenic nutrients.

Keywords Nutrients · Eutrophication · Seagrass health · Seagrass biomass $\cdot$ Redfield ratio $\cdot$ Stable isotopes

\section{Introduction}

Although only 0.1 to $0.2 \%$ of the ocean seabed is occupied by seagrass, it forms a highly productive ecosystem that provides a wide variety of very important functions, such as: protecting shorelines against erosion; trapping and cycling nutrients; providing food for coastal food webs and, creating habitats for an extensive range of wildlife, including commercially important species of fish and crustaceans (Thresher et al., 1992; 
Loneragan et al., 1998; Nagelkerken, 2009; Kennedy et al., 2010). The sensitivity of seagrass species to environmental conditions means they can be used as indicators of ecological processes. For example, elemental stoichiometry and spatial patterns in elemental content of phytoplankton and higher plants (Redfield ratio) have been used to investigate their nutrient status and this approach can also be applied in seagrass (Duarte, 1990) to generate hypotheses about the nature of spatial and temporal variation in ecosystem processes (Fourqurean et al. 1992; Fourqurean and Zieman 2002). Stable isotopes are also being increasingly used as tools to investigate ecosystem processes, such as determining sediment source, nutrient cycling and carbon limitation, as well as their use as indicators of environmental threats to, and stresses on, seagrass ecosystems (Barrón et al., 2004; Kennedy et al., 2004, 2005; Papadimitriou et al., 2005a, b, 2006; Frederiksen et al., 2006; Walton et al., 2014). Research investigating natural and anthropogenic environmental threats has focused on establishing the extent of natural variations in the elemental $(\mathrm{C}, \mathrm{N}, \mathrm{S})$ and stable isotope composition $\left(\delta^{13} \mathrm{C}, \delta^{15} \mathrm{~N}, \delta^{34} \mathrm{~S}\right)$ of seagrass, validating its ability to act as a tracer of anthropogenic nutrient sources and in determining the limits of our ability to recognise anthropogenic impacts from natural environmental change (e.g. Udy et al., 1999; Papadimitriou et al., 2006). However, the success of this type of approach is strongly dependent on understanding the underlying processes that affect stable isotope values. The interpretation of stable isotope values is often limited by a lack of knowledge with regard to either the abiotic/biotic factors that define the incorporation of stable isotopes into their biogeochemical repositories or the range of biogeochemical processes that can subsequently alter any isotopic signature.

Seagrasses are able to absorb nutrients from the water column through their leaves and from the sediments through their roots (Lepoint et al., 2004), and so, the $\delta^{15} \mathrm{~N}$ value of seagrass is influenced by the $\delta^{15} \mathrm{~N}$ values of these sources; hence, their use in monitoring environmental change. Although plants are generally more depleted in ${ }^{15} \mathrm{~N}$ than the nutrient source, the discrimination against the heavier ${ }^{15} \mathrm{~N}$ isotope and preferential incorporation of ${ }^{14} \mathrm{~N}$ in plant tissue can only occur when the supply of $\mathrm{N}$ is in excess of the plant's demand (Evans, 2001). This can lead to seasonal variation, with more positive $\delta^{15} \mathrm{~N}$ values in the summer when growth increases demand for $\mathrm{N}$, becoming more negative in the winter (Fourqurean et al., 2005). Seagrass growth requires a range of elements, but $\mathrm{N}$ and $\mathrm{P}$ are the nutrients that commonly restrict growth (Duarte, 1990; Lee et al., 2007). P limitation increases the supply of N relative to demand providing greater opportunity for ${ }^{15} \mathrm{~N}$ discrimination, and also affects seagrass growth, biomass and size (Udy and Dennison, 1997; Lee et al., 2007). Conversely, increased P supply can boost canopy height and biomass while reducing opportunity for ${ }^{15} \mathrm{~N}$ discrimination (Udy and Dennison, 1997). Positive $\delta^{15} \mathrm{~N}$ values can also result from sewage inputs, fertiliser runoff, atmospheric deposition (Yamamuro et al., 2003) and denitrification (Cline and Kaplan, 1975). Values around $0 \%$ occur as a result of $\mathrm{N}$ fixation (Yamamuro et al., 2003). Negative $\delta^{15} \mathrm{~N}$ values can occur as a result of remineralisation of organic matter that can produce sediments with a $\delta^{15} \mathrm{~N}$ value of $\sim-2 \%$ (Möbius, 2013) and nitrification that can lead to porewater nitrates with $-5 \% \delta^{15} \mathrm{~N}$ values (Yu et al., 2015). Even greater depletion in ${ }^{15} \mathrm{~N}$ has been observed in plants with mycorrhizal associations, leading to values of -8 to $-11 \% \delta^{15} \mathrm{~N}$ (Hobbie et al., 2005), and in marine phytoplankton and bacteria (Liu et al., 2013) and terrestrial plants (Yoneyama et al., 1991) that utilise ammonium as a nitrogen source.

As part of a recent meta-analysis of the $\mathrm{N}$ isotopic values of seagrass species from around the world, Christiaen et al. (2014) reported $\delta^{15} \mathrm{~N}$ values ranged from +17.8 to $-3.2 \%$, with temperate genera, including Zostera, Posidonia and Ruppia, being more enriched in ${ }^{15} \mathrm{~N}$, whereas tropical genera were impoverished (Halodule spp., Halophila spp. and Syringodium spp. being amongst the most depleted). Recently, in a discussion paper, Fourqurean et al. (2015) reported that the global range of $\delta^{15} \mathrm{~N}$ values has increased greatly with the discovery of seagrass beds in Bermuda that had $\delta^{15} \mathrm{~N}$ values that ranged from 8.8 to $-10.6 \%$. However, mean values $( \pm 1 \mathrm{SD})$ were all positive (e.g. Thalassia testudinum $2.2 \pm 3.7 \%$, Halodule sp. $1.6 \pm 3.5 \%$ ) and much more negative means with similar variability were previously reported from Halodule uninervis beds in two bays on the east coast of Qatar $-3.9 \pm 3.2 \%$ o $(n=129)$ and Al Dhakira Bay $-5.2 \pm 2.1 \%$ o $(n=3)$ (Walton et al., 2014), suggesting that these extreme negative values are more common than previously thought. However, the cause for these depleted ${ }^{15} \mathrm{~N}$ values remains unexplained.

Extensive seagrass meadows have been reported along the Qatar coast, with greatest abundances at water depths of between 3 and $8 \mathrm{~m}$, but extending down to around $20 \mathrm{~m}$ below sea level (Sheppard et al., 1992). The extreme environment of the gulf (large seasonal variation in seawater temperatures (18 to $32{ }^{\circ} \mathrm{C}$ ) and high salinity (36 and $45 \mathrm{ppt}$ ) on the east coast (Al-Maslamani et al., 2007), but with more extreme values off the south east and west coasts) exceeds the limits of most seagrass species. Only three species are found in the waters around Qatar: H. uninervis is most widely distributed (Phillips, 2003); less common is Halophila stipulacea; and least frequent is Halophila ovalis (Erftemeijer and Shuail, 2012). Although these three seagrass species may be welladapted to these environmental conditions, they are likely near the threshold of their tolerance.

The current study examines the spatial and temporal variation in the $\delta^{15} \mathrm{~N}$ values of seagrasses, and investigates the likely factors that cause the variation. Systems associated with tropical carbonate sediments are often P limited, as phosphate is bound to the sediments making it less bioavailable (Short, 
1987). Hence, the potential effect of nutrient limitation on seagrass $\delta^{15} \mathrm{~N}$ values is examined in detail in this study. As nutrient analysis of seagrass may not reveal longer-term nutrient limitation (Udy and Dennison, 1997), the current study also surveyed the differences in plant characteristics (biomass, plant height, leaf width, leaves per shoot and percentage cover) and compared them with other regions. Finally, this study investigates the biogeochemical factors (sediment and water column nutrients, sediment $\delta^{15} \mathrm{~N}$ values, sediment depth and sediment composition) as possible influences or causes of the highly variable and unusually depleted $\delta^{15} \mathrm{~N}$ values in the seagrass leaves, reported previously (Al-Maslamani et al., 2012; Walton et al., 2014).

\section{Methods}

\section{Site}

This study was carried out in Al Khor bay, Qatar (lat/long: 25.691, 51.523). The bay is bounded to the west by Al Khor city, to the east by mangrove forest, and with a narrow opening to the sea in the south (Fig. 1). The bay itself contains 420 ha of seagrass, mostly $H$. uninervis, with some $H$. stipulacea and much less H. ovalis (Al-Maslamani et al., 2012, 2013; Walton et al., 2014). There is limited freshwater input from an annual rainfall of $75 \mathrm{~mm}$ (UN, 1997). Maximal tidal range is $1.6 \mathrm{~m}$ and average daily air temperature ranges between 10 and $45^{\circ} \mathrm{C}$, resulting in coastal sea temperatures of 17 to $32^{\circ} \mathrm{C}$ and salinities of 41 to 44 ppt (Al-Maslamani, 2006).

\section{Sample Collection and Preparation}

\section{Isotopic Variation in Seagrass}

Large-Scale Spatial and Seasonal Variation in Isotopic $\delta^{\mathbf{1 5}} \mathrm{N}$ Values in Seagrass Three seasonal surveys of seagrass in Al Khor Bay were conducted in June 2011 (peak growth period), October 2011 (end of growth) and March 2012 (beginning of growth) to determine the consistency of the depleted ${ }^{15} \mathrm{~N}$ isotopic values both spatially and temporally. Spatial variation over the three seasonal surveys was investigated by sampling over a large-scale grid of 37 stations evenly spread across the bay, approximately $500 \mathrm{~m}$ apart (Fig. 1).

During each survey, samples of all seagrass species present (H. uninervis, $H$. stipulacea and $H$. ovalis) were collected at each station by hand and chilled on site before being transferred to the laboratories at the Environmental Science Center, Qatar University. In the laboratory, seagrass leaves (c. 10 leaves per sample) were scraped with a scalpel to remove epiphytes and washed in distilled water before being dried at $60{ }^{\circ} \mathrm{C}$ for $48 \mathrm{~h}$.

Small-Scale Spatial Variation in Isotopic $\delta^{\mathbf{1 5}} \mathrm{N}$ Values in Seagrass In October 2011, to investigate small-scale spatial variation in isotopic values of seagrass, two grids of stations spaced $50 \mathrm{~m}$ apart (with a few additional stations separated by only $10 \mathrm{~m}$ ), were overlaid on areas with a previously observed wide ranges of $\delta^{15} \mathrm{~N}$ values. A $5 \times 5$ station grid was sampled in the eastern end of the bay and a $3 \times 9$ station grid at the western end (see Figs. 1 and 5). At all stations, seagrass was sampled as previously described. In March, only the eastern small-grid stations were resampled to examine consistency of the negative $\delta^{15} \mathrm{~N}$ values.

Isotopic Partitioning Within and Between Species In March 2012, to investigate differences in isotopic discrimination between different parts of the three seagrass species, whole plants of each species were hand dug from the sediment and gently washed in seawater, before being placed on ice. In the laboratory, sand grains were hand-picked from the roots and rhizomes and leaves scraped, then washed in distilled water and separated into leaves, rhizomes and roots, before being dried as described previously.
Fig. 1 Location of sampling points for seagrass and sediments. Small-scale grid stations were sampled in October 2011; large spatial scale grid stations were sampled seasonally

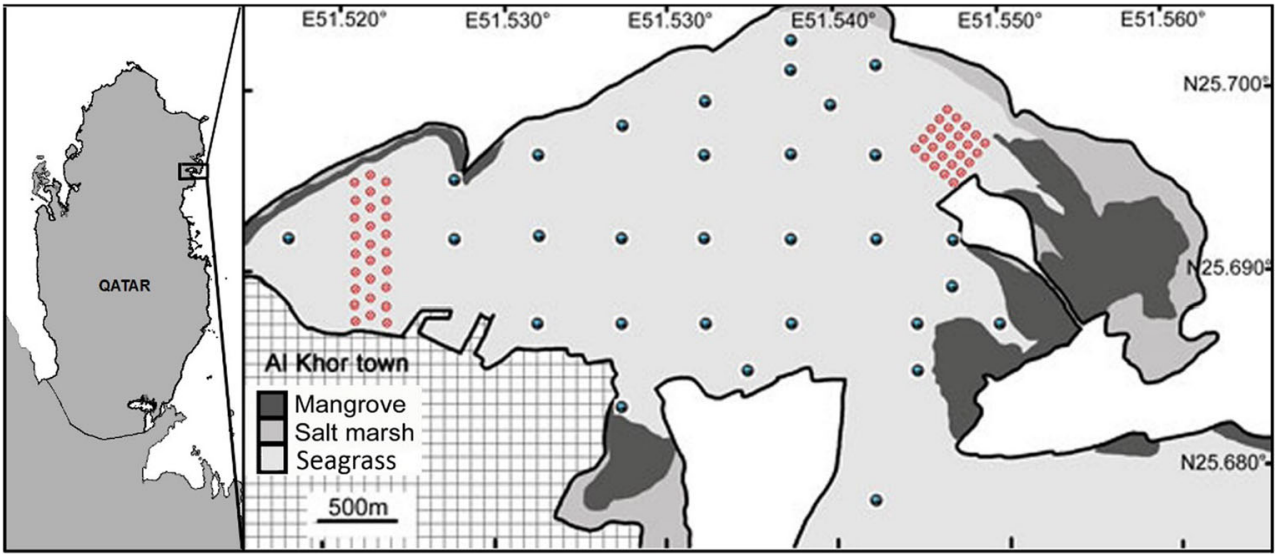




\section{Plant Characteristics}

Seagrass percentage cover was measured in situ per species (the sum for all species being the total seagrass cover) for all sites in the whole-bay sampling grid in October 2011 (Fig. 1). Seagrass cover and species composition was determined from photographs taken by underwater digital camera of $1 \times 1 \mathrm{~m}$ quadrats, each divided into four equal sections of $25 \times 25 \mathrm{~cm}$.

Seagrass biomass cores were taken in October 2011 from the whole-bay large-scale sampling grid $(n=37)$ with a perspex corer (10-cm diameter) to as great a depth as possible. At each sample site, three cores were taken, separated by at least $2 \mathrm{~m}$. Cores were wrapped in aluminium foil on ice until arrival at the laboratory where they were stored frozen until processed. Above-ground material was removed by slicing through the top of the core using a sharp knife. Above-ground living seagrass tissue, was measured to obtain plant height, a 10\% sub-sample was then used for estimating leaves per shoot and leaf width, before being returned to the sample and then washed, dried and weighed. Below-ground material was separated into five 2-cm-deep sections and a final section (if present) of greater than $10-\mathrm{cm}$ depth. Each section was then washed onto a fine sieve and living seagrass tissue was separated by floatation and rinsing through sieves. All obtained material was dried and weighed separately for each depth section.

\section{Investigation of Environmental Factors Possibly Influencing Seagrass Isotopic Values}

Water Column Sub-surface sea water samples in October and March were collected in 1-1 acid-washed flasks, particulate organic matter (POM) removed by vacuum filtering through $\mathrm{GF} / \mathrm{F}$ filters and filtrate preserved by freezing until analysis. The filters were acidified following Kennedy et al. (2004) and analysed for stable isotopes as described earlier. The filtrate was used for seawater nutrients (phosphate, ammonia, nitrite and nitrate) and quantified using a continuous flow nutrient analyser (Skalar). Temperature and salinity were also recorded in situ.

Sediment In June, samples of sediment were taken at each station using a cut-off 60-ml syringe pushed into the sediment up to the 50-ml mark. Water was removed from the surface of the sample by pushing up from the bottom of the syringe with a plunger. The sample was then placed on ice and frozen upon returning to the laboratory, before being prepared for isotopic analysis. Sediment depth was also measured at three points chosen haphazardly for each station and at least $2 \mathrm{~m}$ apart using a graduated 1.4-m-long metal pole c. $1 \mathrm{~cm}$ in diameter driven down into the substrate until it would go no further (using body weight to force it down). Sediment depth was measured to the nearest $1 \mathrm{~cm}$ until sediment depth exceeded $1.3 \mathrm{~m}$.
For the October and March sampling, two extra sediment samples were obtained for porewater analysis from the wholebay large-scale sampling grid $(n=37)$ in the same way as for isotopic analysis described earlier. In the laboratory, porewater was extracted through centrifuging, filtered and frozen until analysis.

Sediment particle size was determined using a Malvern Mastersizer laser diffraction particle analyser. Adsorbed (or available) phosphorus that is surface bound or carbonateassociated in sediments was determined by inductively coupled plasma mass spectrometry (ICP-MS) following extraction in $0.11 \mathrm{M}$ acetic acid, following methods described by Spivakov et al. (1999). Sediment porewater nutrients (phosphate, ammonia, nitrite and nitrate) were quantified using a discrete analyser (Easychem).

Seagrass Nutrient Profile In October and March, extra samples of seagrass were collected at each station in both largeand small-scale grids and processed as for isotopic analysis described in the following section, before being frozen for subsequent nutrient analysis. Total phosphorus in plant tissue was determined by ICP-MS following extraction with $1.0 \mathrm{M}$ hydrochloric acid, and nitrogen and carbon content was obtained from the stable isotope analysis.

\section{Isotopic Analysis}

Prior to stable isotope analysis, sediment samples were sequentially acidified with $0.1 \mathrm{M} \mathrm{HCl}$ and oven dried repeatedly until addition of $\mathrm{HCl}$ resulted in no bubbling, indicating all carbonates had been removed (Kennedy et al., 2004). Plant material was collected and treated as described previously. All samples were oven dried for $48 \mathrm{~h}$ before being homogenised and weighed into tin cups (Elemental Microanalysis Ltd.) and subsequently analysed for ${ }^{13} \mathrm{C}$ and ${ }^{15} \mathrm{~N}$ isotopes using a PDZ Europa ANCA-GSL elemental analyser linked to a PDZ Europa 20:20 isotope ratio mass spectrometer (Sercon Ltd., Cheshire, UK).

\section{Data Analysis}

Multiple correlation analysis was used to determine which variables were correlated, and only those that exhibited a significant relationship were analysed further. Data assumptions such as normality and homogeneity of variance were tested for prior to further analysis by regression or analysis of variance using Minitab 14. Data is presented as mean \pm standard deviation. The correlations between measured plant health and environmental variables on the $\delta^{15} \mathrm{~N}$ values of seagrass were the first to be assessed. Secondly, the nutrients and nutrient ratios in seagrass, sediment and water were assessed for nutrient limitation based on deviations from the Redfield ratio. The 
$\mathrm{C} / \mathrm{N}$ ratios vs $\mathrm{N}$ and $\mathrm{C} / \mathrm{P}$ ratios vs $\mathrm{P}$ were compared, as well as the relationships between plant and sediment $\delta^{15} \mathrm{~N}$ values and plant $\mathrm{C} / \mathrm{N}$ ratios, $\mathrm{C} / \mathrm{P}$ ratios and $\mathrm{N} / \mathrm{P}$ ratios.

\section{Results}

\section{Isotopic Variation in Seagrass}

Large Spatial Scale and Seasonal Variations in Isotopic $815 \mathrm{~N}$ Values in Seagrass

The initial survey of the seagrass beds in June 2011 indicated high spatial variability in $H$. uninervis $\delta^{15} \mathrm{~N}$ values across the bay ( +3.6 to $-9.9 \%)$, which was consistent across the subsequent seasonal samplings in October $2011(+3.3$ to $-9.2 \%$ ) and March 2012 (+3.0 to $-9.2 \%$, Fig. 2). Spatially, values, over all three seagrass species ranged from slightly enriched stations close to $\mathrm{Al}$ Khor City $(+3.7 \%)$ to highly depleted values $(-10.3 \%)$ at some stations at the eastern end of the bay. Analysis of variance of the H. uninervis leaf $\delta^{15} \mathrm{~N}$ values between seasons at each station in the large-scale grid suggested that there were significant differences $(F=5.31$, $p=0.007)$ and a Tukey's test indicated that seagrass samples from stations in October $\left(\delta^{15} \mathrm{~N}=-4.08 \pm 3.17 \%\right.$ ) were significantly more depleted than those from June $(-1.86 \pm 1.74 \%$ ) (ANOVA, $p<0.05$ ) but not different from March values $(-3.50 \pm 2.80 \%)$.

The temporal consistency of the spatial distribution of $\delta^{15} \mathrm{~N}$ values was tested by regression of values observed at each station between seasons (Figs. 3 and 4). The relationship between the months was in both cases linear, but did not fall on a 1:1 line between site and season. The slope of the regression line of June and October values is close to 1 (0.97) indicating that there was consistency in the spatial pattern of $\delta^{15} \mathrm{~N}$ values between these months, with intercept indicating the mean $( \pm 1$ SD) depletion between June and October at each station being $-2.5 \pm 2.3 \%$. Comparing between October and March, the slope of the linear relationship (0.6) indicates that those stations with lower $\delta^{15} \mathrm{~N}$ values in October exhibited a further depletion over the winter, while those with higher $\delta^{15} \mathrm{~N}$ values exhibited little or no depletion or enrichment.

\section{Small-Scale Spatial Variation in Isotopic $\delta^{15} N$ Values in Seagrass}

The range in $\delta^{15} \mathrm{~N}$ values of seagrass in the small-scale grids overlapped with that observed in the large-scale grid (west grid +3.7 to $-5.5 \%$ and east grid -1.9 to $-10.7 \%$ ). Variance in the October $\delta^{15} \mathrm{~N}(\%)$ values for $H$. uninervis leaves within the large-scale and each of the small-scale grids was homogenous (Bartlett's test statistic $=4.24, p=0.12$ ), indicating that there was no significant difference in the variability in $\delta^{15} \mathrm{~N}(\%)$ values over both large- (500-m interval) and smallscale (50- to $10-\mathrm{m}$ intervals) sampling grids (Fig. 5). However, analysis of variance indicated there were significant differences in mean values between small-scale grids $(F=23.3, p<0.001)$. Tukey's pairwise comparisons suggested that the west grid had significantly lessdepleted values (mean $\delta^{15} \mathrm{~N} \pm \mathrm{SD}=-1.9 \pm 1.7 \%$ ) than the east grid (mean $\delta^{15} \mathrm{~N} \pm \mathrm{SD}=-6.5 \pm 4.7 \%$ ). In March, only a few leaf samples were obtained from the small grids due to the winter leaf fall and $\delta^{15} \mathrm{~N}$ values ranged from -2.5 to $-12.4 \%$ o $(n=7)$.

\section{Inter-and Intra-Species Variability in $815 \mathrm{~N}$ in Seagrasses}

Differences were found between the isotopic signature of leaves, roots and rhizomes of the three seagrass species. In March 2012 a significant correlation $(p<0.05)$ was seen in $\delta^{15} \mathrm{~N}$ values of H. uninervis leaves, rhizomes and roots, that deviated from a 1:1 relationship, and regression analysis suggested that as both leaf and rhizome became more depleted in ${ }^{15} \mathrm{~N}$ the isotopic values were similar at $-9 \%$, with the rhizome becoming more consistently depleted than the leaf when $\delta^{15} \mathrm{~N}$ values increase (Fig. 6). This was indicative of some isotopic partitioning between different parts of the plant but only when $\delta^{15} \mathrm{~N}$ values are high. Only six root samples were of sufficient weight to provide accurate isotope analysis, preventing regression analysis. However, no significant difference in $\delta^{15} \mathrm{~N}$ values $(p \geq 0.05)$ was observed between roots and leaves or rhizomes.

The co-occurrence of both $H$. uninervis and H. stipulacea at a number of stations permitted direct comparison of leaf $\delta^{15} \mathrm{~N}$ values in the two species (Fig. 7). In June $(F=7.12$, $p=0.024)$ and October $(F=15.61, p=0.002)$, there was a significant linear relationship, between leaf $\delta^{15} \mathrm{~N}$ values of the two species. At each station, H. uninervis was depleted in ${ }^{15} \mathrm{~N}$ compared to $H$. stipulacea by, on average, $2.5 \pm 1.4$ and 5.5 $\pm 1.8 \%$ during June and October, respectively. Comparisons with values from March and with $H$. ovalis were not possible due to the small number of co-occurring samples.

\section{Seagrass Characteristics, Biomass and Distribution}

A detailed study of seagrass biomass, leaf length, shoot number and cover was performed in October 2011. H. uninervis was the dominant seagrass present at almost all stations and at greater densities than $H$. stipulacea or $H$. ovalis. Greatest seagrass coverage between 65 and $95 \%$ was noted in the deepest parts of the bay, with sparse seagrass in shallower areas and biomass varying from 5 to $900 \mathrm{~g} \mathrm{DW} \mathrm{m}^{-2}$ (mean $\pm 1 \mathrm{SD}=198 \pm 229$ ) (Supplement 1). Canopy height for $H$. uninervis varied from $3 \mathrm{~cm}$ in some marginal areas to $10.4 \mathrm{~cm}$ in the central areas, with the number of leaves per shoot following a similar pattern to that of canopy height and 
Fig. 2 Variation in Halodule uninervis leaf $\delta^{15} \mathrm{~N}$ values (\%) in Al Khor Bay at stations visited during June and October 2011 and March 2012. Black bubbles are positive and white bubbles are negative. The size of the bubble represents the distance of numerical value from zero

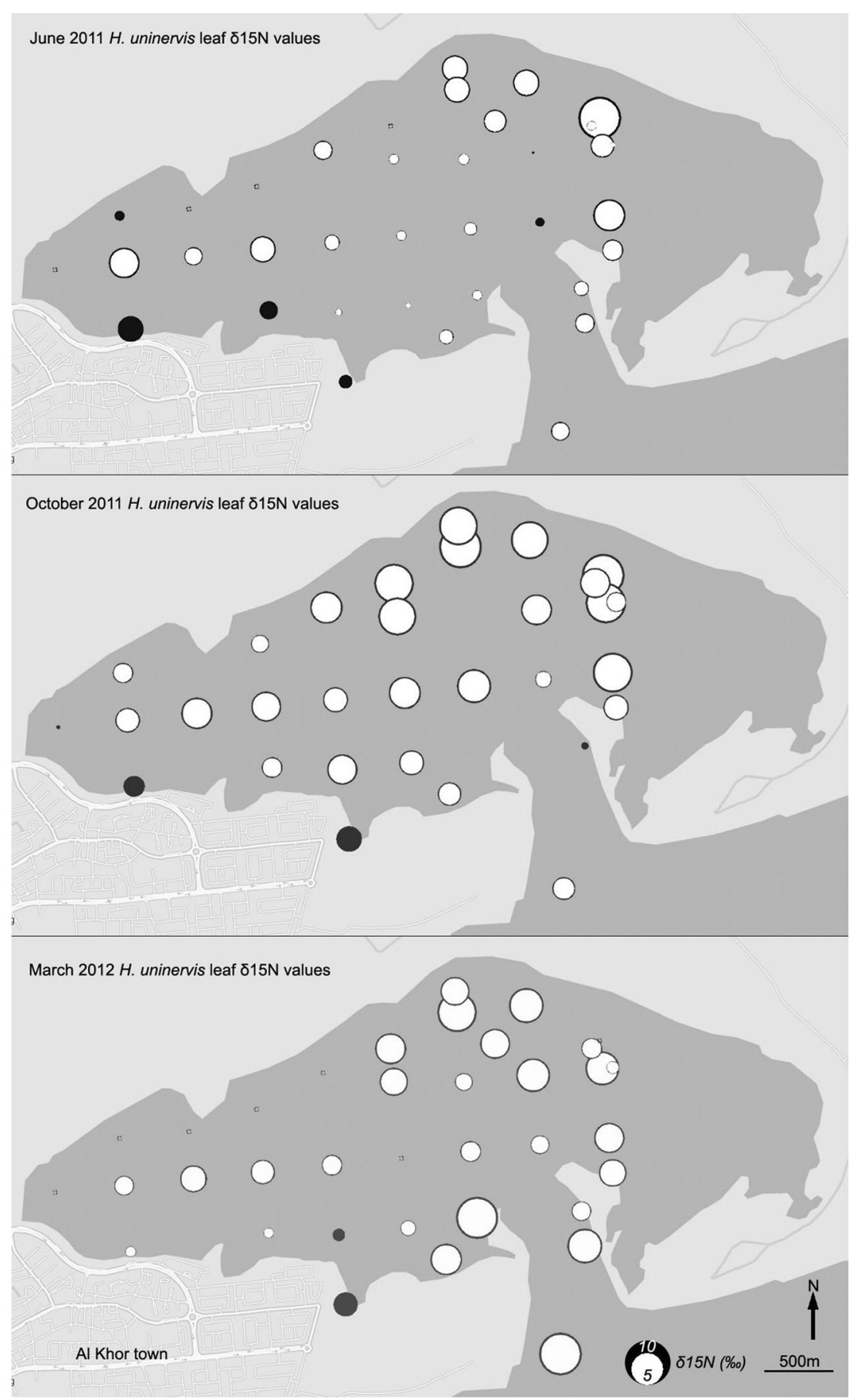

varied between 2.3 and 6.6 leaves per shoot. $H$. uninervis leaf width varied from 0.05 to $0.11 \mathrm{~cm}$ with a mean of $0.5 \mathrm{~cm}$. H. stipulacea is mostly only present in the deeper western end of the bay where it has three to six leaves per shoot and with a canopy height of 3.1 to $4.6 \mathrm{~cm}$ (see Supplement 2 for more detail). Although not captured in the biomass sampling, there was a seasonal loss of leaves during the winter months, especially in the shallow and intertidal areas. None of the seagrass characteristics correlated with leaf $\delta^{15} \mathrm{~N}$ values.

\section{Investigation of Environmental Factors Possibly Influencing Seagrass Isotopic Values}

\section{Sediments and Water Column}

Sediment depth averaged $61 \mathrm{~cm}$ and ranged from 3.3 to $>140 \mathrm{~cm}$, with the shallowest sediments closest to the shore and deeper sediments in the deeper central bay area. The mean sediment composition was 62:35:3 sand/silt/clay. Neither 
Fig. 3 Comparison of $\delta 15 \mathrm{~N}$ values for Halodule uninervis leaves at each station on the largescale spatial grid between June and October

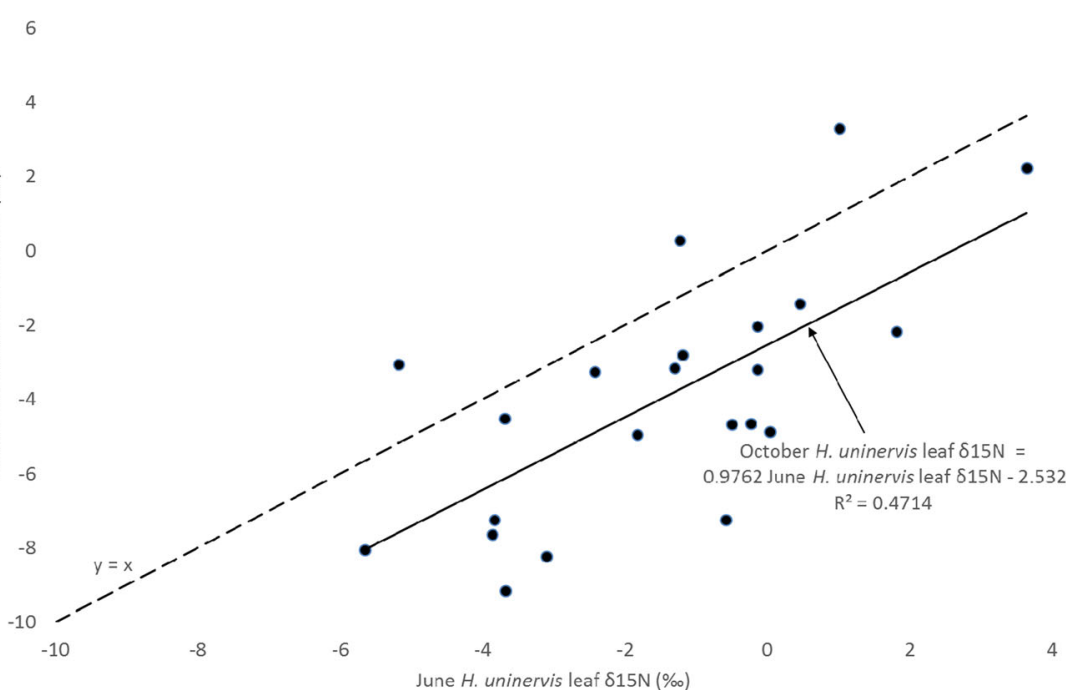

sediment depth nor composition correlated with sediment or seagrass $\delta^{15} \mathrm{~N}$ values.

The $\delta^{15} \mathrm{~N}$ of suspended POM was enriched, and showed neither significant seasonal variation $(t=-0.31, p=0.9)$ (October $3.1 \pm 0.5 \%$, March $3.1 \pm 0.9 \%$ ) nor consistent spatial variation. The $\delta^{15} \mathrm{~N}$ of sediment organic matter was also enriched, but variable; ranging from 0.13 to $4.8 \%$ over the study period. Data from October $(0.13-4.8 \%$ ) and June $(0.7-$ $3.3 \%$ ) sampling dates were highly correlated $(F=7.26$, $p<0.001)$, but neither dataset was correlated with March $(0.5-1.9 \%)$. The average increase in $\delta^{15} \mathrm{~N}$ values of $0.22 \%$ at each station indicated that October sediments were enriched in ${ }^{15} \mathrm{~N}$ compared with June, although these differences in $\delta^{15} \mathrm{~N}$ values was not found to be significant $(p>0.05)$.

In June and October, regression analysis indicated a weak $\left(r^{2}=39.7 \%\right.$ and $r^{2}=33.8 \%$, respectively) but significant relationship between $\delta^{15} \mathrm{~N}$ values of $H$. uninervis leaves and those of sediments (June: $F=18.63, p<0.001$ and October: $F=28.08$, $p<0.001)$. The average ${ }^{15} \mathrm{~N}$ depletion of H. uninervis compared to sediment at each station was $3.1 \pm 2.2$ and $5.2 \pm 2.7 \%$ in June and October, respectively (Fig. 8). However, by March, the leaves were depleted by an average of $-4.6 \pm 2.3 \%$ and there was no significant correlation between $\delta^{15} \mathrm{~N}$ values of H. uninervis leaves and sediments. In October, in the western small-scale grid, discrimination between sediment and H. uninervis leaves was $3.9 \pm 1.4 \%$ but was much greater in the eastern small-scale grid $(7.4 \pm 3.5 \%$ ). In no cases were there significant correlations between $\delta^{15} \mathrm{~N}$ values of either H. stipulacea or H. ovalis and those of sediments.

\section{Nutrient Content of Seawater, Sediment, Porewater and Seagrass}

Water column total $\mathrm{N}$ was low $(0.7$ to $7.5 \mu \mathrm{M})$, commensurate with the oligotrophic setting of the study site. Porewater nutrients showed no spatial patterns, but appeared to be seasonally reduced in March with the N/P ratio indicating that $\mathrm{N}$
Fig. 4 Comparison of $\delta^{15} \mathrm{~N}$ values for Halodule uninervis leaves at each station on the largescale spatial grid between March and October

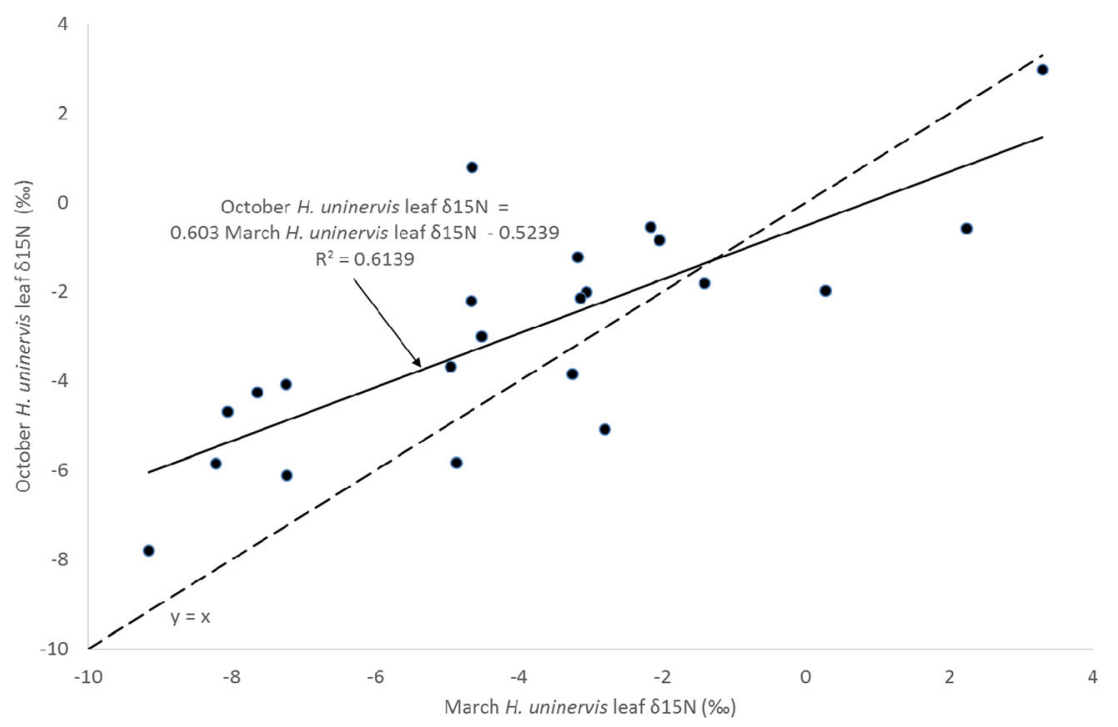




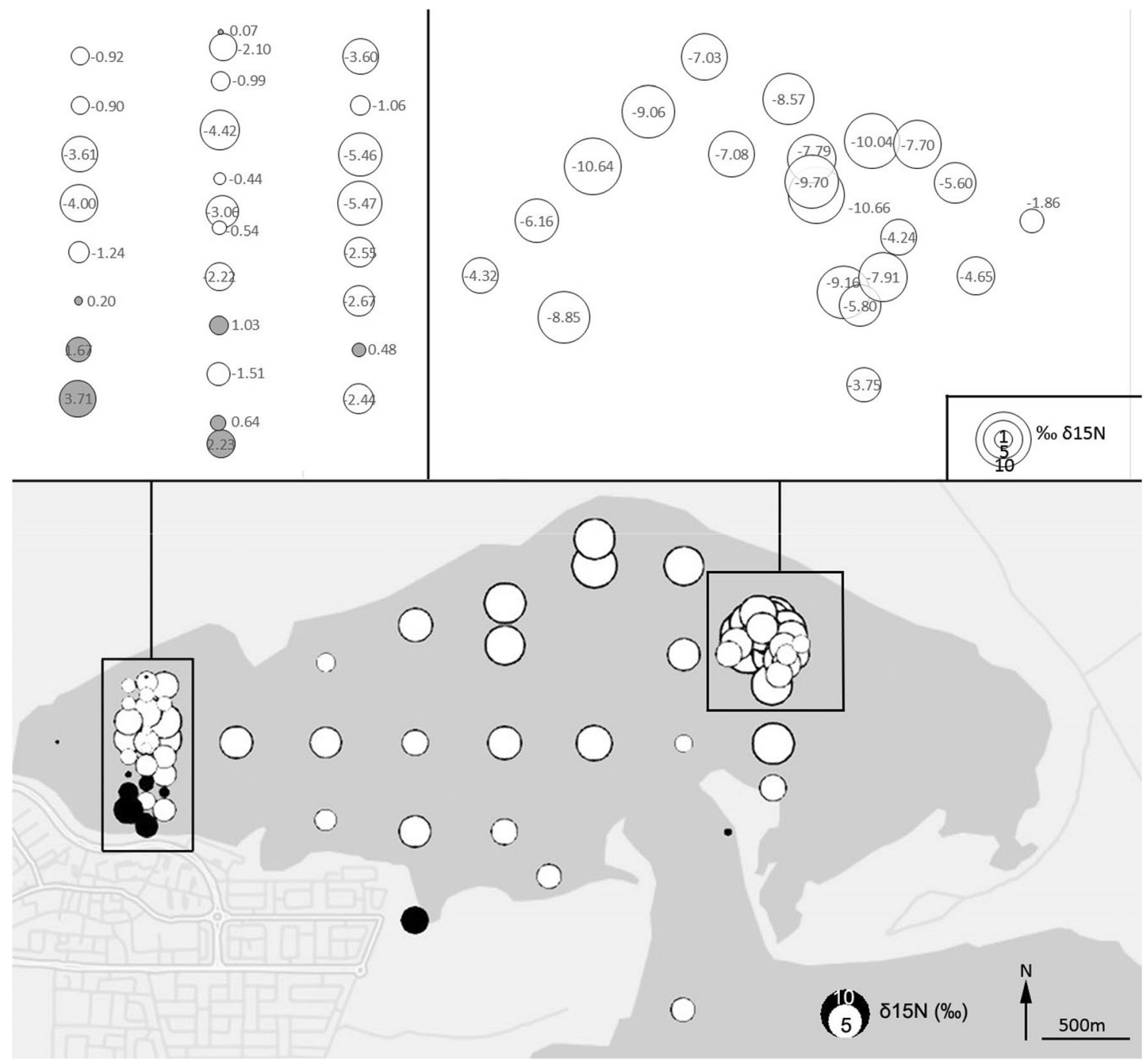

Fig. 5 Variation in Halodule uninervis $\delta^{15} \mathrm{~N}$ in $\mathrm{Al}$ Khor Bay at stations visited during October 2011 sampling session with inserts of small-scale sampling grids. Black/grey bubbles are positive and white bubbles are negative

Fig. 6 Comparison of $\delta^{15} \mathrm{~N}$ values in seagrass leaf and rhizome in H. uninervis in March 2012

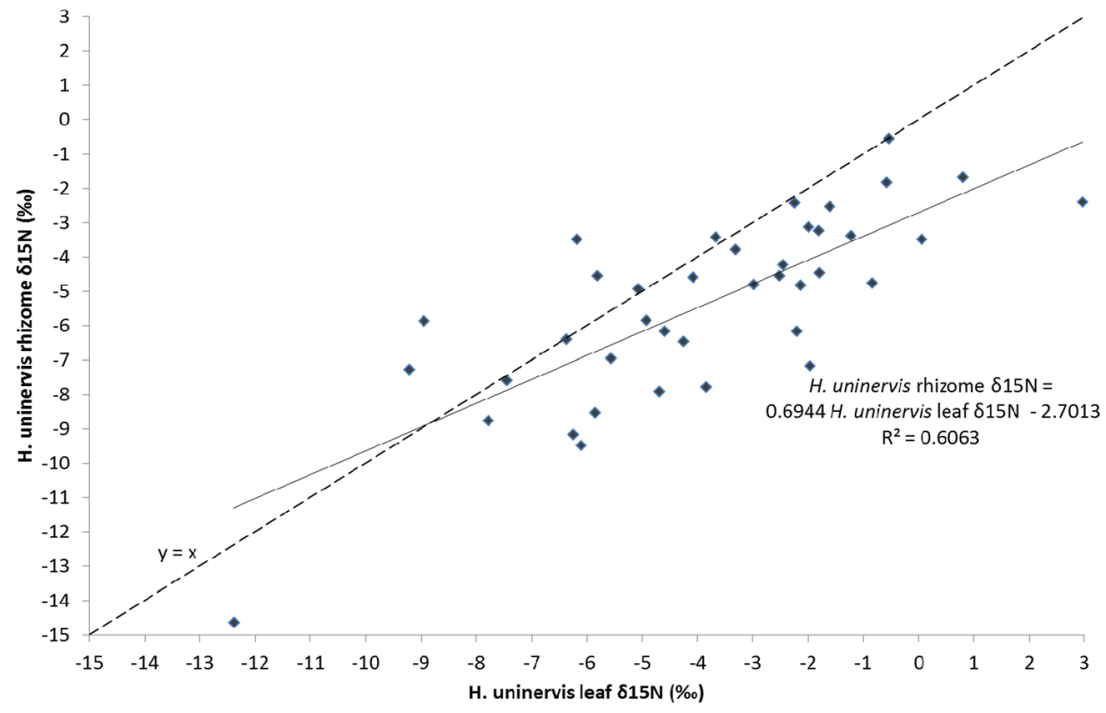


Fig. 7 Seasonal variation in the relationship between $\delta^{15} \mathrm{~N}$ values of $H$. uninervis and $H$. stipulacea samples from the same stations

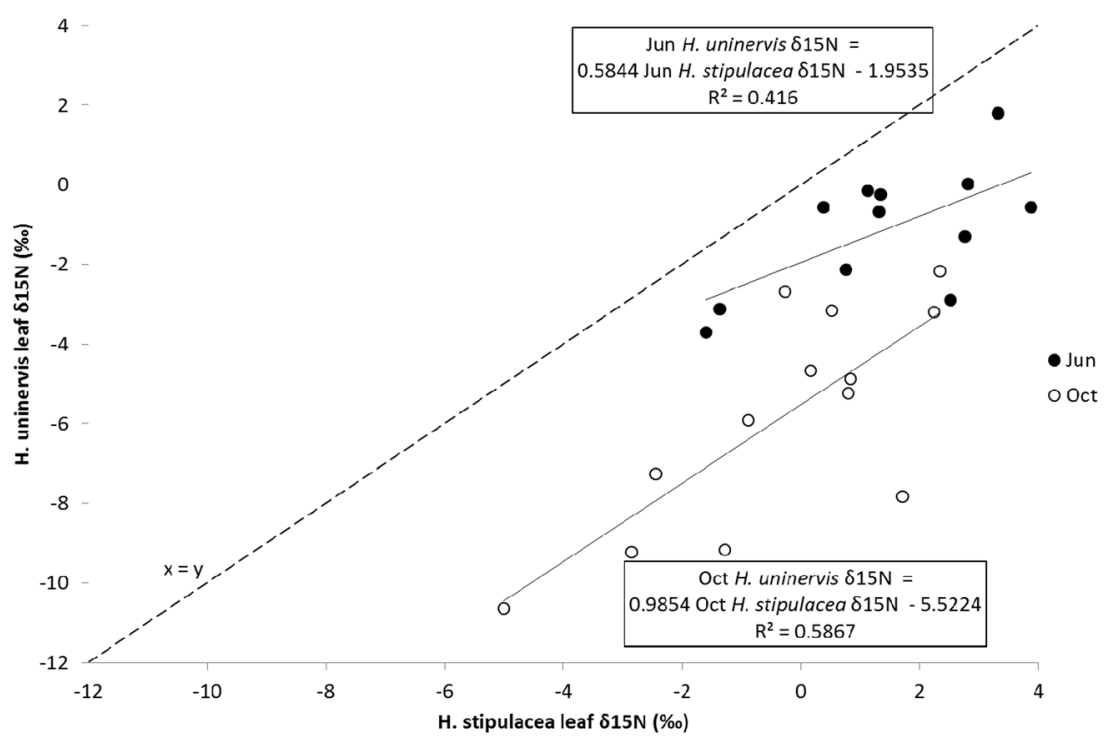

depletion was more severe than P (Table 1). Sediment adsorbed $\mathrm{P}$ showed no spatial or seasonal patterns. Neither the $\mathrm{P}$ and $\mathrm{N}$ values, nor the $\mathrm{N} / \mathrm{P}$ ratio of the seagrass leaves showed any significant spatial or temporal patterns of variation. However, the variance of $H$. uninervis leaf $\mathrm{N}, \mathrm{P}$ and $\mathrm{N} / \mathrm{P}$ ratio was significantly greater in March than in October. Neither sediment nor any of porewater nutrients were significantly correlated with the $H$ uninervis leaf $\delta^{15} \mathrm{~N}$ values. Moreover, $H$ uninervis leaf $\delta^{15} \mathrm{~N}$ values had no significant relationship with leaf nutrient content or ratios in October and March in the large sampling grid (no nutrient samples were taken in June). Some weak correlations were found between nutrient content and $\delta^{15} \mathrm{~N}$ values of $H$. uninervis leaves when all data points were incorporated, including those in the small grids; however, the significance was reliant on a small number (less than four) of outlying data points that exerted a strong influence on the result.

\section{Discussion}

The current study reports some of the most extreme negative $\delta^{15} \mathrm{~N}$ values ever reported for seagrass (as low as $-12.4 \%$ ) and some of the most highly spatially variable (values varied over $15.4 \%$ in a relatively small area of only $655 \mathrm{ha}$ ). The global variation in seagrass $\delta^{15} \mathrm{~N}$ values reported to date is from +17.8 to $-10.6 \%$ (Christiaen et al., 2014; Fourqurean et al., 2015) with Halodule spp. and Halophila spp. (the two genera found in Qatar) being amongst the most depleted (Christiaen et al., 2014). Unusually low $\delta^{15} \mathrm{~N}$ values may be more of a response to location than a trait of certain genera. Fourqurean et al. (2015) recently reported $T$. testudinum, a genera not previously associated with depleted ${ }^{15} \mathrm{~N}$ values, to have leaves with lower $\delta^{15} \mathrm{~N}$ values of 8.0 to $-10.1 \%$ o than Halodule sp. at the same location, which varied from 5.6 to $-8.9 \%$ and Halophila decipiens, which was much less depleted. These negative values from
Fig. 8 Seasonal variation in the relationship between the $\delta^{15} \mathrm{~N}$ values of $H$. uninervis and sediment, sampled from the same stations (March data are not included as correlation was not significant)

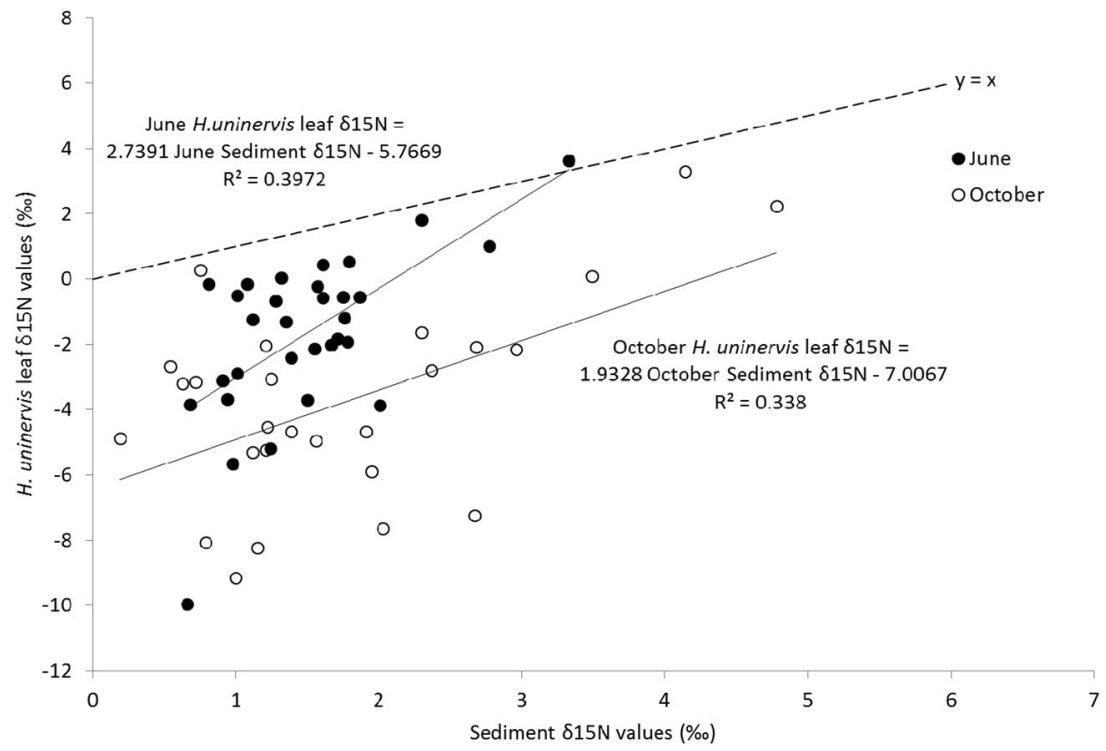


Table 1 Sediment, pore water and water column nutrients and leaf $\mathrm{P}$ and $\mathrm{N}$. Means are reported $\pm 1 \mathrm{SD}$

\begin{tabular}{lll}
\hline Nutrients & October & March \\
\hline Sediment adsorbed $\mathrm{P}\left(\mu \mathrm{mol} \mathrm{g} \mathrm{g}^{-1}\right)$ & $0.71 \pm 0.2$ & $0.70 \pm 0.2$ \\
Sediment porewater $\mathrm{P}(\mu \mathrm{M})$ & $0.05 \pm 0.05$ & $0.007 \pm 0.004$ \\
Sediment porewater total N $(\mu \mathrm{M})$ & $1.13 \pm 0.1$ & $0.20 \pm 0.07$ \\
Sediment porewater molar N:P & $52.5 \pm 59.7$ & $37.2 \pm 23.0$ \\
Water column total $\mathrm{N}(\mu \mathrm{M})$ & $3.9 \pm 2$ & \\
H. uninervis leaf $\mathrm{P}\left(\mu \mathrm{mol} \mathrm{g}{ }^{-1}\right)$ & $48.7 \pm 8.8$ & $48.7 \pm 18.5$ \\
H. uninervis leaf $\mathrm{N}\left(\mu \mathrm{mol} \mathrm{g}{ }^{-1}\right)$ & $1998.2 \pm 153.5$ & $2220.7 \pm 557.0$ \\
H. uninervis leaf molar N/P & $42.2 \pm 6.8$ & $56.0 \pm 41.5$ \\
\hline
\end{tabular}

the middle of the Bermuda platform were suggested to be the result of unspecified benthic processes and ammonification, although this could not be confirmed as there were no sediment chemistry data. In the current study, there was a slight localized but significant enrichment in ${ }^{15} \mathrm{~N}$ in seagrass samples in the western end of the bay, resulting in some positive $\delta^{15} \mathrm{~N}$ values, which suggests that anthropogenic inputs of nitrogen are entering the bay from $\mathrm{Al}$ Khor city. This is likely to be the result of ground water or the overflow of tertiary-treated wastewater during the winter months, when evaporation does not exceed supply (personal communication, Dr. Abdel-Moati 2014). Indeed, seagrass $\delta^{15} \mathrm{~N}$ has previously been used to identify and trace the input of sewage $\mathrm{N}$ from its enriched ${ }^{15} \mathrm{~N}$ value (McClelland and Valiela, 1998; Lepoint et al., 2004; Lassauque et al., 2010). One possible influence could be the mangrove forest at the eastern end of the bay, where senescent mangrove leaf $\delta^{15} \mathrm{~N}$ values are known to average $-2 \%$ (Walton et al., 2014). However, application of isotopic mixing models (Walton et al., 2014) shows that there is almost no outwelling of mangrove material beyond the immediate boundary of mangrove area, indicating there is unlikely to be any influence from the mangrove on the ${ }^{15} \mathrm{~N}$ content of sediments or seagrasses across the bay.

\section{Temporal and Spatial Variation}

The consistency of the variance at both large $(500 \mathrm{~m})$ and small $(50 \mathrm{~m})$ sampling scales indicates that the cause of the negative $\delta^{15} \mathrm{~N}$ values is operating at a scale of less than $50 \mathrm{~m}$, and observed differences in $\delta^{15} \mathrm{~N}$ values of $3 \%$ in samples less than $10 \mathrm{~m}$ apart indicate that the influencing factor differed over the scale of just a few metres. At the smaller scale, correlation between the $\delta^{15} \mathrm{~N}$ values of different seagrass species from the same sample station (even though $H$. stipulacea was significantly less depleted in ${ }^{15} \mathrm{~N}$ than $H$. uninervis) shows the factors influencing these values were similar over the scale of a metre.

Sampling during the three growth periods indicated that $\delta^{15} \mathrm{~N}$ values of $H$. uninervis are influenced by season, being significantly less depleted in June than October or March. Cline and Kaplan (1975) report that metabolic rates are inversely related to isotopic discrimination, not only for plants but also for denitrifying bacteria. Therefore, in winter, when there is less demand for nitrogen, discrimination is likely to be greater. This is the most probable explanation behind the seasonality of the ${ }^{15} \mathrm{~N}$ isotopic values in $H$. uninervis leaves in $\mathrm{Al}$ Khor bay, where reduced discrimination was observed during periods of high growth in June when demand for nitrogen is peaking, becoming increasingly depleted as growth stops during the winter period in October and before growth restarts in March. Despite these small seasonal changes, the consistency of the $H$. uninervis $\delta^{15} \mathrm{~N}$ values at any one sampling station throughout the year indicate the underlying cause of ${ }^{15} \mathrm{~N}$ depletion is spatially consistent over the period studied.

\section{Intra-/Inter- Specific Variation}

The $\delta^{15} \mathrm{~N}$ values of $H$. uninervis leaves and rhizomes were significantly correlated $\left(R^{2}=60 \%\right)$ although some partitioning occurred, as rhizomes are generally less depleted in ${ }^{15} \mathrm{~N}$ than leaves, becoming more similar at extreme ${ }^{15} \mathrm{~N}$ depletion. In contrast, studies on H. uninervis in Indonesia found no significant difference between leaf and rhizome $\delta^{15} \mathrm{~N}$ values (Christianen et al., 2012). Seagrasses in general are often found in nutrient poor coastal waters where they are able to outcompete other macrophytes because of their relatively low demand for nutrients (Duarte, 1990), combined with their ability to maintain uptake rates of inorganic $\mathrm{P}$ and $\mathrm{N}$ even in these low nutrient conditions. Lepoint et al. (2002) list a number of strategies employed by seagrass to cope with low nutrient environments, including the storage of nutrients for future deployment, internal recycling, and re-absorption of nutrients from senescent leaves. A more positive $\delta^{15} \mathrm{~N}$ signal in rhizomes was also found in Posidonia oceanica and was reportedly due to the increased concentrations of ${ }^{15} \mathrm{~N}$-enriched amino acids used to store excess nitrogen in preparation for remobilization in times of nutrient limitation (Vizzini et al., 2003). The authors suggest that as amino acids are more enriched in ${ }^{15} \mathrm{~N}$ than bulk material they can be used as an indicator of the changes in $\mathrm{N}$ reserves in different parts of the plant.

The relative depletion of ${ }^{15} \mathrm{~N}$ in the leaves of $H$. stipulacea compared to those of $H$. uninervis and the lack of correlation between sediment and the leaf $\delta^{15} \mathrm{~N}$ values of $H$. stipulacea and $H$. ovalis (compared with $H$. uninervis) indicates these two seagrass species may have different $\mathrm{N}$ uptake mechanisms than H. uninervis (as suggested by Evans (2001)).

\section{Seagrass Characteristics}

Since discrimination against ${ }^{15} \mathrm{~N}$ within the plant only occurs when supply of $\mathrm{N}$ is greater than assimilation rates (Evans, 2001), the nutrient profiles of seagrass and sediments and their 
$\mathrm{N} / \mathrm{P}$ and $\mathrm{C} / \mathrm{N}$ ratios were checked to see if they correlated with seagrass leaf $\delta^{15} \mathrm{~N}$ values. It is thought that when there are low $\mathrm{N}$ concentrations or where $\mathrm{C} / \mathrm{N} / \mathrm{P}$ ratios indicate that $\mathrm{N}$ is limiting, then discrimination will be lower. Hence, $\mathrm{N}$ discrimination would be expected to increase with increasing $\mathrm{N}$ concentration, leading to seagrass being depleted in ${ }^{15} \mathrm{~N}$ (Campbell and Fourqurean, 2009). The C/N values of the seagrass species present in $\mathrm{Al}$ Khor bay range from 16 to 22 , which is approximately central in the range of values (mean 20) presented in the review of seagrass nutrient content by Duarte (1990). In contrast, N/P ratios of $H$. uninervis and H. stipulacea leaves in $\mathrm{Al}$ Khor bay were all $>30$, indicating $\mathrm{P}$ limitation (Duarte, 1990; Johnson et al., 2006), and with the exception of Tanzania, were much greater than ratios reported at any other locations globally (Table 2). P-limited systems are often associated with tropical carbonate sediments, such as those found in Qatar, where phosphate is bound to sediments making it less bioavailable (Short, 1987). However, in the current study, no significant relationship was detected between $H$. uninervis leaf $\delta^{15} \mathrm{~N}$ values and leaf $\mathrm{N} / \mathrm{P}$ ratios. This is in agreement with the study by Mellors et al. (2005), where none of the nutrient parameters measured, including nutrient ratios, correlated with $H$. uninervis biomass. It should be noted that Ferdie and Fourqurean (2004) argue that seagrass leaf N/P ratio is a poor indicator of nutrient limitation, which can only be truly determined through sequential nutrient addition mesocosm experiments.

The seagrass community of Al Khor bay appears to be healthy, with $H$. uninervis coverage that ranged from 0 to $100 \%$, averaging almost $50 \%$ and a mean above- and below-ground biomass of 198 and $663 \mathrm{~g} \mathrm{~m}^{-2}$, respectively (Supplement 1). Similar values were obtained for aboveground biomass of $H$. uninervis (94-281 $\mathrm{g} \mathrm{m}^{-2}$ ) from three sites in Kuwait (Al-Bader et al., 2014). These values and that of the current study are much greater than the mean aboveand below-ground biomass values of 27 and $60 \mathrm{~g} \mathrm{~m}^{-2}$ obtained from 25 studies around the world (Duarte and Chiscano, 1999). Canopy height appears to be fairly typical at $7 \mathrm{~cm}$ (range 3 to $12 \mathrm{~cm}$ ) and similar to that of Udy and Dennison (1997) and Al-Bader et al. (2014). Elsewhere, reported leaf biomass has varied from 7 to $40 \mathrm{~g} \mathrm{~m}^{-2}$ for $H$. uninervis and H. stipulacea in the Red Sea (Wahbeh, 1988) and values of $13.8 \mathrm{~g} \mathrm{~m}^{-2}$ have been reported for $H$. uninervis in Indonesia (Christianen et al., 2012). This suggests that the high biomass found in Qatar is perhaps typical of $H$. uninervis growing in the western Arabian Gulf, which is much higher than values reported elsewhere. The ratios of above-/below-ground biomass (mean \pm 1 SD: $0.63 \pm 0.59$ ) correlated with neither leaf nor sediment $\delta^{15} \mathrm{~N}$ values, nor with sediment nutrient concentrations, although at the eulittoral stations closest to Al Khor City the ratio averaged 1.44 , possibly due to the increased nutrient concentrations noted around the urbanised area. Duarte and Chiscano (1999) suggested that above-ground seagrass biomass is more responsive to nutrient increase, showing higher growth than below-ground biomass. The high biomass of the seagrass beds in Al Khor bay suggests H. uninervis is not stressed and perhaps explains why these proxies for seagrass health do not appear to correlate with the $\delta^{15} \mathrm{~N}$ values of $H$. uninervis leaves.

\section{Influence of Water Column and Sediment Processes}

Comparison of nutrient supply with other $H$. uninervis beds around the world indicates that water column total $\mathrm{N}$ in Al Khor $(0.7$ to $7.5 \mu \mathrm{M})$ is towards the lower end of the global range of 1.2 to $28.9 \mu \mathrm{MN}$ (Daby, 2003; Christianen et al., 2012). Porewater N in $\mathrm{Al} \mathrm{Khor}(0.2$ to $1.13 \mu \mathrm{MN})$ was much lower than those reported from seagrass beds elsewhere, which range from 1.8 to 144.4 $\mu \mathrm{M}$ N globally (Udy and Dennison, 1997; Yamamuro et al., 2001; Mellors et al., 2005; Christianen et al., 2012). Porewater $\mathrm{P}$ in $\mathrm{Al}$ Khor $(0.007$ to $0.05 \mu \mathrm{M} \mathrm{P})$ was also much lower than that reported from seagrass beds elsewhere, which range from 0.3 to $3.2 \mu \mathrm{M}$ P globally (Udy and Dennison, 1997; Yamamuro et al., 2001; Mellors et al., 2005; Christianen et al., 2012). In contrast, adsorbed $\mathrm{P}$ in $\mathrm{Al}$ Khor sediments was $0.7 \mu \mathrm{mol} \mathrm{g}^{-1}$; towards the higher end of the range reported by Mellors et al. (2005) that spanned from 0.02 to $0.82 \mu \mathrm{mol} \mathrm{g}^{-1}$, indicating that much of the $\mathrm{P}$ is bound up in the sediments. These data suggest that although both nutrients are limited, the supply of $\mathrm{N}$ is in excess of demand relative to $\mathrm{P}$, which could explain why the isotopic values are generally so depleted in ${ }^{15} \mathrm{~N}$. In a similar manner, when $\mathrm{N}$ has been experimentally supplied in excess of demand, the $\delta^{15} \mathrm{~N}$ values of the leaves of $H$. uninervis growing in those sediments was very depleted (see Table 2) (Udy and Dennison (1997) and Udy et al. (1999)).

The relative enrichment in ${ }^{15} \mathrm{~N}$ of the POM, combined with the oligotrophic and homogeneous nature of the bay water precludes it as a major contributor to the observed heterogeneous and highly depleted seagrass $\delta^{15} \mathrm{~N}$ values. Seagrasses utilise both ammonia and nitrate, which are absorbed by both leaves and roots from the water column and sediment (Lepoint et al., 2004). The correlations between sediments and plant and the lack of correlation with the water column $\delta^{15} \mathrm{~N}$ values indicates that $H$. uninervis $\delta^{15} \mathrm{~N}$ values are linked to processes associated within the sediment. Seagrasses can uptake $\mathrm{N}$ in various forms, including $\mathrm{NH}_{4}{ }^{+}, \mathrm{NO}_{3}$ urea and amino acids and these $\mathrm{N}$ sources are all generally found in higher concentrations in sediment pore waters. Given the anoxic status of most seagrass sediments, it is unlikely that processes that lead to depleted nitrate values, such as partial nitrification can be the cause of the observed depletions. In $\mathrm{Al}$ Khor, $\mathrm{NH}_{4}^{+}$accounts for $87 \%$ of the total inorganic $\mathrm{N}$ in pore waters, and in common with other seagrass species $\mathrm{NH}_{4}^{+}$uptake rates are up to two orders of magnitude greater than for $\mathrm{NO}_{3}{ }^{2-}$, in both H. uninervis and H. stipulacea roots (Vonk et al., 2008; Alexandre et al., 2014). Experimental studies in a range of 
Table 2 The percentage content of nitrogen and phosphorus by dry weight, molar N/P ratio and sample number of Halodule uninervis, Halophila stipulacea and Halophila ovalis from various locations around the world and from the current study (large grid)

\begin{tabular}{|c|c|c|c|c|c|c|c|}
\hline Species & Location & $\% \mathrm{~N}$ & $\% \mathrm{P}$ & $\mathrm{N} / \mathrm{P}$ molar & Number & $\begin{array}{l}\delta 15 \mathrm{~N} \\
(\%)\end{array}$ & Source \\
\hline H. uninervis & Green Island, N. Qld, Aust. & 2.40 & 0.26 & $20: 1$ & 3 & $1.7^{\mathrm{a}}$ & Udy et al. (1999) \\
\hline H. uninervis & Green Island, N. Qld, Aust. & 3.0 & 0.3 & $22: 1$ & 3 & $-2.0^{\mathrm{b}}$ & Udy et al. (1999) \\
\hline H. uninervis & Moreton Bay, S.E. Qld, Aust. & 2.40 & 0.24 & $22: 1$ & 3 & $2.4^{\mathrm{a}}$ & Udy and Dennison (1997) \\
\hline H. uninervis & Moreton Bay, S.E. Qld, Aust. & 3.2 & 0.24 & $22: 1$ & 3 & $-8.8^{\mathrm{b}}$ & Udy and Dennison (1997) \\
\hline H. uninervis & Magnetic Island, N. Qld, Aust. & 0.92 & 0.15 & $14: 1$ & 3 & - & Birch (1975) \\
\hline H. uninervis & Global average & 2.40 & 0.19 & $27: 1$ & 15 & - & Duarte (1990) \\
\hline H. uninervis & Lugger Bay, N. Qld, Aust. & $4.64 \pm 0.27$ & $0.28 \pm 0.01$ & $37: 1$ & 3 & - & Mellors et al. (2005) \\
\hline H. uninervis & Meunga Ck, N. Qld, Aust. & $6.30 \pm 0.25$ & $0.45 \pm 0.07$ & $32: 1$ & 3 & - & Mellors, et al. (2005) \\
\hline H. uninervis & Cape Pallarenda, N. Qld, Aust & $3.32 \pm 0.08$ & $0.32 \pm 0.01$ & $23: 1$ & 3 & - & Mellors, et al. (2005) \\
\hline H. uninervis & Geoffrey Bay, N. Qld, Aust. & $4.45 \pm 0.18$ & $0.28 \pm 0.02$ & $35: 1$ & 3 & - & Mellors, et al. (2005) \\
\hline H. uninervis & Horseshoe Bay,N. Qld, Aust. & $4.19 \pm 0.14$ & $0.21 \pm 0.05$ & $44: 1$ & 3 & - & Mellors, et al. (2005) \\
\hline H. uninervis & Long Bay, N. Qld, Aust. & 3.47 & 0.23 & $33: 1$ & 3 & - & Mellors, et al. (2005) \\
\hline H. uninervis & Port Dennison, N. Qld, Aust. & $3.02 \pm 0.46$ & $0.18 \pm 0.04$ & $38: 1$ & 3 & - & Mellors, et al. (2005) \\
\hline H. uninervis & Green Island, Aust. & $2.09 \pm 0.23$ & $0.3 \pm 0.01$ & $16: 1$ & 3 & 2.68 & Yamamuro et al. (2001) \\
\hline H. uninervis & Dravuni Island, Fiji & $1.55 \pm 0.13$ & $0.2 \pm 0.1$ & $17: 1$ & 2 & -0.06 & Yamamuro et al. (2001) \\
\hline H. uninervis & Aqaba, Red Sea, Jordan & $2.37 \pm 0.07$ & - & - & 36 & - & Wahbeh (1988) \\
\hline H. uninervis & W. A., Aust. & - & - & $18: 1$ & 36 & - & Atkinson and Smith (1983) \\
\hline H. uninervis & Shark Bay, W. A., Aust. & 1.78 & 0.12 & $34: 1^{\mathrm{c}}$ & 161 & - & Burkholder et al. (2013) \\
\hline H. uninervis & Banten Bay, Indonesia & $1.49 \pm 0.21$ & $0.19 \pm 0.03$ & $17: 1$ & 16 & - & Kiswara et al. (2009) \\
\hline H. uninervis & E. Kalimantan, Indonesia & $2.21 \pm 0.02$ & $0.18 \pm 0.01$ & $13: 1$ & 10 & $1.63^{\mathrm{d}}$ & Christianen et al. (2012) \\
\hline H. uninervis & Asian Average (5 sites) & $1.50 \pm 0.06$ & $0.27 \pm 0.01$ & $12: 1$ & 17 & - & Terrados, et al. (1999) \\
\hline H. uninervis & Tanzania & 1.64 & 0.05 & $73: 1$ & - & - & (Hemminga et al. (1999)) \\
\hline H. uninervis (Oct) & Al Khor, Qatar & $2.76 \pm 0.19$ & $0.15 \pm 0.02$ & $42: 1$ & 76 & -4.08 & This study \\
\hline H. uninervis (Mar) & Al Khor, Qatar & $3.14 \pm 0.73$ & $0.14 \pm 0.06$ & $56: 1$ & 41 & -3.50 & This study \\
\hline H. uninervis (Oct) & Al Dhakira, Qatar & $2.73 \pm 0.25$ & $0.17 \pm 0.07$ & $36: 1$ & 3 & 0.06 & Walton (unpublished data) \\
\hline H. uninervis (Mar) & Al Dhakira, Qatar & $3.37 \pm 0.17$ & $0.18 \pm 0.01$ & $41: 1$ & 3 & -1.4 & Walton (unpublished data) \\
\hline H. ovalis & Cockle Bay, N. Qld, Aust & 0.72 & 0.16 & $10: 1$ & 2 & - & Birch (1975) \\
\hline H. ovalis & Global average & 0.70 & 0.18 & $9: 1$ & 2 & - & Duarte (1990) \\
\hline H. ovalis & Swan-Canning Est, W.A., Aust. & - & - & $8: 1$ & - & - & Connell and Walker (2001) \\
\hline H. ovalis & Picnic Bay, N. Qld, Aust. & $2.36 \pm 0.02$ & $0.36 \pm 0.19$ & $14: 1$ & 3 & - & Mellors et al. (2005) \\
\hline H. ovalis & W. A., Aust & - & - & $13: 1$ & 29 & - & Atkinson and Smith (1983) \\
\hline H. ovalis & Laem Yong Lam, S.W. Thailand & 1.30 & 0.13 & $22: 1$ & - & 2.32 & Yamamuro and Chirapart (2005) \\
\hline H. ovalis & Laem Yong Lam, S.W. Thailand & 1.98 & 0.22 & $20: 1$ & 1 & 3.21 & Yamamuro et al. (2001) \\
\hline H. ovalis & Fiji & 2.50 & 0.33 & $17: 1$ & - & -1.70 & Yamamuro et al. (2001) \\
\hline H. ovalis & Green Island, Aust. & $2.50 \pm 0.03$ & $0.43 \pm 0.1$ & $15: 1$ & 2 & 2.00 & Yamamuro et al. (2001) \\
\hline H. ovalis & Dravuni Island, Fiji & $2.51 \pm 0.10$ & $0.44 \pm 0.01$ & $14: 1$ & 2 & 1.41 & Yamamuro et al. (2001) \\
\hline H. ovalis & Asian Average (5 sites) & $1.89 \pm 0.08$ & $0.37 \pm 0.02$ & $11: 1$ & 17 & - & Terrados et al. (1999) \\
\hline H. ovalis (Oct) & Al Khor, Qatar & 2.18 & - & - & 1 & -3.73 & This study \\
\hline H. ovalis (Mar) & Al Khor, Qatar & - & $0.04 \pm 0.01$ & - & 4 & - & This study \\
\hline H. stipulacea & Shark Bay, W. A., Aust. & 1.38 & 0.12 & $24: 1$ & 51 & - & Burkholder, et al. (2013) \\
\hline H. stipulacea & Aqaba, Red Sea, Jordan & $1.33 \pm 0.11$ & - & & 36 & - & Wahbeh (1988) \\
\hline H. stipulacea (Oct) & Al Khor, Qatar & $1.96 \pm 0.30$ & $0.10 \pm 0.03$ & $49: 1$ & 17 & 0.44 & This study \\
\hline H. stipulacea (Mar) & Al Khor, Qatar & $2.45 \pm 0.30$ & $0.16 \pm 0.11$ & $41: 1$ & 5 & 0.15 & This study \\
\hline
\end{tabular}

${ }^{\mathrm{a}}$ Ambient values from fertilisation experiments

${ }^{\mathrm{b}}$ Enriched with $\mathrm{N}$ in fertilisation experiments

${ }^{\mathrm{c}}$ Median values

${ }^{\mathrm{d}}$ Unfertilized values

terrestrial plants demonstrate strong fractionation of $\delta^{15} \mathrm{~N}$ when $\mathrm{N}$ is supplied as $\mathrm{NH}_{4}^{+}$, with plant tissue $\delta^{15} \mathrm{~N}$ values being up to 7 to $16 \%$ lighter than the supplied source (Yoneyama et al., 1991; Emmerton et al., 2001; Ariz et al., 2011). In seagrass, the fertilisation experiment of Udy and Dennison (1997) concur with these studies, but the results may not be applicable to our study site as much higher concentrations of $\mathrm{NH}_{4}^{+}$were available than are present in pore waters in $\mathrm{Al} \mathrm{Khor.} \mathrm{Emmerton} \mathrm{et} \mathrm{al,} \mathrm{(2001)} \mathrm{showed} \mathrm{that} \mathrm{as} \mathrm{the}$ proportion of $\mathrm{NH}_{4}^{+}$taken up by plants increases the difference between source and plant $\delta^{15} \mathrm{~N}$ diminishes, reaching equivalence when all $\mathrm{N}$ added is absorbed. They induced differences 
in ${ }^{15} \mathrm{~N}$ abundance between source and plants of up to $-8 \%$ in Eriophorum vaginatum, equivalent to the difference between sediment and plant ${ }^{15} \mathrm{~N}$ for $H$. uninervis in Al Khor, but only when less than $20 \%$ of supplied $\mathrm{N}$ had been taken up. While $\mathrm{NH}_{4}{ }^{+}$concentrations in pore waters in $\mathrm{Al}$ Khor are low, this does not confirm low $\mathrm{N}$ supply; plant nutrient ratios did not indicate $\mathrm{N}$, but $\mathrm{P}$ limitation, and seagrass biomass was at the high end of the range of observed values globally. Significant loss from the porewater $\mathrm{NH}_{4}{ }^{+} / \mathrm{NH}_{3}$ pool through diffusion to the overlying water column from sediments is likely. Thus, the high degree of ${ }^{15} \mathrm{~N}$ fractionation observed could be consistent with uptake of a relatively small proportion of the overall $\mathrm{NH}_{4}{ }^{+}$supply.

In shallow carbonate environments, especially in subtropical areas such as the Arabian Gulf, the variably depleted $\delta^{15} \mathrm{~N}$ values for seagrass biomass relative to observed, less variable, $\mathrm{N}$ sources of SPOM and sediments across the bay indicate benthic $\mathrm{N}$ cycling as the most likely cause of negative ${ }^{15} \mathrm{~N}$ values and ${ }^{15} \mathrm{~N}$ fractionation during $\mathrm{NH}_{4}{ }^{+}$uptake. The spatial correlation of $\delta^{15} \mathrm{~N}$ values between $H$. uninervis and H. stipulacea suggests consistent differences in ${ }^{15} \mathrm{~N}$ fractionation between the species, as has been observed in experimental studies of co-existing terrestrial plants (Emmerton et al., 2001). The high discrimination seen in this study could be due to a highly depleted $\mathrm{N}$ source, resulting from one of a number of processes. For example, recent research discovered a number of fungi and microbial endophytes that inhabit seagrass root systems (Shoemaker and Wyllie-Echeverria, 2013 and references therein). In low nutrient environments, terrestrial plants with fungal symbionts tend to rely on the symbiont for the supply of $\mathrm{N}$, which is normally very depleted and fractionated by -8 to $-10 \%$ (Hobbie et al., 2005). However, the impact of these fungal associations on $\delta^{15} \mathrm{~N}$ values in seagrass is unknown.

In conclusion, we have observed consistently highly depleted $\delta^{15} \mathrm{~N}$ values in the bay studied here, which appear to be caused by processes occurring over very small spatial scales (a few metres). The high biomass present suggests that nutrient limitation does not appear to play a role in affecting H. uninervis leaf $\delta^{15} \mathrm{~N}$ values, even though $\mathrm{N} / \mathrm{P}$ ratios indicate that $\mathrm{P}$ is the limiting nutrient in $\mathrm{Al} \mathrm{Khor} \mathrm{bay.} \mathrm{The} \mathrm{consistently}$ divergent $\delta^{15} \mathrm{~N}$ values for three species of seagrass growing in the same relatively ${ }^{15} \mathrm{~N}$-enriched sediment $\mathrm{N}$ pool suggest that these differences may be due to benthic processing and/or $\mathrm{N}$ uptake mechanisms. Similar areas of low, depleted ${ }^{15} \mathrm{~N}$ in seagrasses have been recorded elsewhere in the world (Christiaen et al., 2014). Ammonium demand relative to supply, extent of ammonium dissociation, and P limitation have been identified as the most likely causes of the observed ${ }^{15} \mathrm{~N}$ depletions. Mycorrhizal associations offer another possible explanation for the magnitude of ${ }^{15} \mathrm{~N}$ depletion recorded in the seagrass leaves in Al Khor. The conditions causing the strongest depletions observed to date occur in geographically distinct locations in Bermuda (Fourqurean et al 2015) and Qatar (present study) and both also display very strong gradients in ${ }^{15} \mathrm{~N}$ values across short distances. The paradoxically high biomass of seagrass found in these nutrient limited areas emphasises the need for further research to understand the common factors that support good growth and result in these highly depleted $\delta^{15} \mathrm{~N}$ signals as they are likely present at other locations globally. In the wider context, the current study observed some of the most extreme, negative and highly spatially variable $\delta^{15} \mathrm{~N}$ values ever reported for seagrass. These results demonstrate the need for adequate spatial and temporal sampling when working with nitrogen stable isotopes in either as sources in food web studies or as tracers of anthropogenic nutrients.

Acknowledgments This study was made possible by a grant from Qatar National Research Foundation (QNRF) under the National Priorities Research Programme (NPRP) 09-129-018 "Nutrient cycling in shallow marine ecosystems". The paper's content is solely the responsibility of the authors and does not necessarily represent the official views of QRNF. We are indebted to Caesar Flonasca Sorino and Marwa Mustufa Al-Azhari at the Environmental Science Center, Qatar University, for the endless processing of these samples. We thank the two anonymous reviewers and the editor Dennis Swaney for their constructive comments that have greatly improved this manuscript.

Open Access This article is distributed under the terms of the Creative Commons Attribution 4.0 International License (http:// creativecommons.org/licenses/by/4.0/), which permits unrestricted use, distribution, and reproduction in any medium, provided you give appropriate credit to the original author(s) and the source, provide a link to the Creative Commons license, and indicate if changes were made.

\section{References}

Al-Bader, D.A., D.A. Shuail, R. Al-Hasan, and P. Suleman. 2014. Intertidal seagrass Halodule uninervis: factors controlling its density, biomass and shoot length. Kuwait Journal of Science 41: 171192.

Al-Maslamani, I., 2006. Feeding and nutrition in the marine shrimp Penaeus semisulcatus. School of Ocean Sciences. Bangor University, Bangor, PhD Thesis, p. 179.

Al-Maslamani, I., L. Le Vay, H. Kennedy, and D.A. Jones. 2007. Feeding ecology of the grooved tiger shrimp Penaeus semisulcatus De Haan (Decapoda : Penaeidae) in inshore waters of Qatar, Arabian Gulf. Marine Biology 150: 627-637.

Al-Maslamani, I., M.E.M. Walton, H. Kennedy, and L. Le Vay. 2012. Sources of primary production supporting food webs in an arid coastal embayment. Marine Biology 159: 1753-1762.

Al-Maslamani, I., M.E.M. Walton, H.A. Kennedy, M. Al-Mohannadi, and L. Le Vay. 2013. Are mangroves in arid environments isolated systems? Life-history and evidence of dietary contribution from inwelling in a mangrove-resident shrimp species. Estuarine, Coastal and Shelf Science 124: 56-63.

Alexandre, A., D. Georgiou, and R. Santos. 2014. Inorganic nitrogen acquisition by the tropical seagrass Halophila stipulacea. Marine Ecology-an Evolutionary Perspective 35: 387-394. 
Ariz, I., Cruz, C., Moran, J.F., Gonzalez-Moro, M.B., Garcia-Olaverri, C., Gonzalez-Murua, C., Martins-Loucao, M.A., Aparicio-Tejo, P.M., 2011. Depletion of the heaviest stable N isotope is associated with NH4+/NH3 toxicity in NH4 +-fed plants. Bmc Plant Biology 11.

Atkinson, M.J., and S.V. Smith. 1983. C:N:P ratios of benthic marine plants. Limnology and Oceanography 28: 568-574.

Barrón, C., N. Marbà, J. Terrados, H. Kennedy, and C.M. Duarte. 2004. Community metabolism and carbon budget along a gradient of seagrass (Cymodocea nodosa) colonization. Limnology and Oceanography 49: 1642-1651.

Birch, W.R. 1975. Some chemical and calorific properties of tropical marine angiosperms compared with those of other plants. Journal of Applied Ecology 12: 201-212.

Burkholder, D.A., J.W. Fourqurean, and M.R. Heithaus. 2013. Spatial pattern in seagrass stoichiometry indicates both N-limited and Plimited regions of an iconic P-limited subtropical bay. Marine Ecology Progress Series 472: 101-115.

Campbell, J.E., and J.W. Fourqurean. 2009. Interspecific variation in the elemental and stable isotope content of seagrasses in South Florida. Marine Ecology Progress Series 387: 109-123.

Christiaen, B., R.J. Bernard, B. Mortazavi, J. Cebrian, and A.C. Ortmann. 2014. The degree of urbanization across the globe is not reflected in the $\delta 15 \mathrm{~N}$ of seagrass leaves. Marine Pollution Bulletin 83: 440-445.

Christianen, M.J.A., L.L. Govers, T.J. Bouma, W. Kiswara, J.G.M. Roelofs, L.P.M. Lamers, and M.M. van Katwijk. 2012. Marine megaherbivore grazing may increase seagrass tolerance to high nutrient loads. Journal of Ecology 100: 546-560.

Cline, J.D., and I.R. Kaplan. 1975. Isotopic fractionation of dissolved nitrate during denitrification in the eastern tropical north pacific ocean. Marine Chemistry 3: 271-299.

Connell, E.L., and D.I. Walker. 2001. Nutrient cycling associated with the seagrass Halophila ovalis in the Swan-Canning Estuary based on seasonal variations in biomass and tissue nutrients. Hydrological Processes 15: 2401-2409.

Daby, D. 2003. Some quantitative aspects of seagrass ecology in a coastal lagoon of Mauritius. Marine Biology 142: 193-203.

Duarte, C.M. 1990. Seagrass nutrient content. Marine Ecology Progress Series 67: 201-207.

Duarte, C.M., and C.L. Chiscano. 1999. Seagrass biomass and production: a reassessment. Aquatic Botany 65: 159-174.

Emmerton, K.S., T.V. Callaghan, H.E. Jones, J.R. Leake, A. Michelsen, and D.J. Read. 2001. Assimilation and isotopic fractionation of nitrogen by mycorrhizal and nonmycorrhizal subarctic plants. New Phytologist 151: 513-524.

Erftemeijer, P.L.A., and D.A. Shuail. 2012. Seagrass habitats in the Arabian Gulf: distribution, tolerance thresholds and threats. Aquatic Ecosystem Health \& Management 15: 73-83.

Evans, R.D. 2001. Physiological mechanisms influencing plant nitrogen isotope composition. Trends in Plant Science 6: 121-126.

Ferdie, M., and J.W. Fourqurean. 2004. Responses of seagrass communities to fertilization along a gradient of relative availability of nitrogen and phosphorus in a carbonate environment. Limnology and Oceanography 49: 2082-2094.

Fourqurean, J.W., and J.C. Zieman. 2002. Nutrient content of the seagrass Thalassia testudinum reveals regional patterns of relative availability of nitrogen and phosphorus in the Florida Keys USA. Biogeochemistry 61: 229-245.

Fourqurean, J.W., J.C. Zieman, and G.V.N. Powell. 1992. Phosphorous limitation of primary production in Florida Bay: evidence from C:N: $\mathrm{P}$ ratios of the dominant seagrass Thalassia testudinium. Limnology \& Oceanography 37: 162-171.

Fourqurean, J.W., S.P. Escorcia, W.T. Anderson, and J.C. Zieman. 2005. Spatial and seasonal variability in elemental content, delta C-13, and delta N-15 of Thalassia testudinum from South Florida and its implications for ecosystem studies. Estuaries 28: 447-461.
Fourqurean, J.W., S.A. Manuel, K.A. Coates, W.J. Kenworthy, and J.N. Boyer. 2015. Water quality, isoscapes and stoichioscapes of seagrasses indicate general $\mathrm{P}$ limitation and unique $\mathrm{N}$ cycling in shallow water benthos of Bermuda. Biogeosciences Discussions 12: 9751-9791.

Frederiksen, M.S., M. Holmer, J. Borum, and H. Kennedy. 2006. Temporal and spatial variation of sulfide invasion in eelgrass (Zostera marina) as reflected by Its sulfur isotopic composition. Limnology and Oceanography 51: 2308-2318.

Hemminga, M.A., N. Marbà, and J. Stapel. 1999. Leaf nutrient resorption, leaf lifespan and the retention of nutrients in seagrass systems. Aquatic Botany 65: 141-158.

Hobbie, E., A. Jumpponen, and J. Trappe. 2005. Foliar and fungal $15 \mathrm{~N}$ : $14 \mathrm{~N}$ ratios reflect development of mycorrhizae and nitrogen supply during primary succession: testing analytical models. Oecologia 146: $258-268$.

Johnson, M.W., K.L. Heck, and J.W. Fourqurean. 2006. Nutrient content of seagrasses and epiphytes in the northern Gulf of Mexico: evidence of phosphorus and nitrogen limitation. Aquatic Botany 85: 103-111.

Kennedy, H., Beggins, J., Duarte, C.M., Fourqurean, J.W., Holmer, M., Marba, N., Middelburg, J.J., 2010. Seagrass sediments as a global carbon sink: isotopic constraints. Global Biogeochemical Cycles 24.

Kennedy, H., E. Gacia, D.P. Kennedy, S. Papadimitriou, and C.M. Duarte. 2004. Organic carbon sources to SE Asian coastal sediments. Estuarine Coastal and Shelf Science 60: 59-68.

Kennedy, H., Papadimitriou, S., Marba, N., Duarte, C.M., Serrao, C., Arnould-Haord, S., 2005. How are seagrass processes, genetics and chemical composition monitored? . in: Borum, J., Duarte, C.M., Krause-Jensen, D., Greve, T.H. (Eds.). European seagrasses: an introduction to monitoring and management, http://www. seagrasses.org, pp. 54-62.

Kiswara, W., N. Behnke, P. van Avesaath, A.H.L. Huiskes, P.L.A. Erftemeijer, and T.J. Bouma. 2009. Root architecture of six tropical seagrass species, growing in three contrasting habitats in Indonesian waters. Aquatic Botany 90: 235-245.

Lassauque, J., G. Lepoint, T. Thibaut, P. Francour, and A. Meinesz. 2010. Tracing sewage and natural freshwater input in a Northwest Mediterranean bay: evidence obtained from isotopic ratios in marine organisms. Marine Pollution Bulletin 60: 843-851.

Lee, K.-S., S.R. Park, and Y.K. Kim. 2007. Effects of irradiance, temperature, and nutrients on growth dynamics of seagrasses: a review. Journal of Experimental Marine Biology and Ecology 350: 144 175.

Lepoint, G., P. Dauby, and S. Gobert. 2004. Applications of C and N stable isotopes to ecological and environmental studies in seagrass ecosystems. Marine Pollution Bulletin 49: 887-891.

Lepoint, G., S. Millet, P. Dauby, S. Gobert, and J.M. Bouquegneau. 2002. Annual nitrogen budget of the seagrass Posidonia oceanica as determined by in situ uptake experiments. Marine Ecology Progress Series 237: 87-96.

Liu, K.-K., S.-J. Kao, K.-P. Chiang, G.-C. Gong, J. Chang, J.-S. Cheng, and C.-Y. Lan. 2013. Concentration dependent nitrogen isotope fractionation during ammonium uptake by phytoplankton under an algal bloom condition in the Danshuei estuary, northern Taiwan. Marine Chemistry 157: 242-252.

Loneragan, N.R., R.A. Kenyon, D.J. Staples, I.R. Poiner, and C.A. Conacher. 1998. The influence of seagrass type on the distribution and abundance of postlarval and juvenile tiger prawns (Penaeus esculentus and P. semisulcatus) in the western Gulf of Carpentaria, Australia. Journal of Experimental Marine Biology and Ecology 228: 175-195.

McClelland, J.W., and I. Valiela. 1998. Changes in food web structure under the influence of increased anthropogenic nitrogen inputs to estuaries. Marine Ecology Progress Series 168: 259-271. 
Mellors, J., M. Waycott, and H. Marsh. 2005. Variation in biogeochemical parameters across intertidal seagrass meadows in the central Great Barrier Reef region. Marine Pollution Bulletin 51: 335-342.

Möbius, J. 2013. Isotope fractionation during nitrogen remineralization (ammonification): implications for nitrogen isotope biogeochemistry. Geochimica et Cosmochimica Acta 105: 422-432.

Nagelkerken, I., 2009. Evaluation of nursery function of mangroves and seagrass beds for tropical decapods and reef fishes: patterns and underlying mechanisms. in: Nagelkerken, I. (Ed.). Ecological connectivity among tropical coastal ecosystems, pp. 357-399.

Papadimitriou, S., H. Kennedy, D.P. Kennedy, and J. Borum. 2005a. Seasonal and spatial variation in the organic carbon and nitrogen concentration and their stable isotopic composition in Zostera marina (Denmark). Limnology and Oceanography 50: 1084-1095.

Papadimitriou, S., H. Kennedy, D.P. Kennedy, C.M. Duarte, and N. Marbá. 2005b. Sources of organic matter in seagrass-colonized sediments: a stable isotope study of the silt and clay fraction from Posidonia oceanica meadows in the western Mediterranean. Organic Geochemistry 36: 949-961.

Papadimitriou, S., H. Kennedy, R.M.N.V. Rodrigues, D.P. Kennedy, and T.H.E. Heaton. 2006. Using variation in the chemical and stable isotopic composition of Zostera noltii to assess nutrient dynamics in a temperate seagrass meadow. Organic Geochemistry 37: 1343-1358.

Phillips, R.C. 2003. The seagrasses of the Arabian Gulf and Arabian region. In World atlas of seagrasses, ed. E.P. Green and F.T. Short, 74-81. California: University of California Press.

Sheppard, C., A. Price, and C. Roberts. 1992. Marine ecology of the Arabian region: patterns and processes in extreme tropical environments. London: Academic.

Shoemaker, G., and S. Wyllie-Echeverria. 2013. Occurrence of rhizomal endophytes in three temperate northeast pacific seagrasses. Aquatic Botany 111: 71-73.

Short, F.T. 1987. Effects of sediment nutrient on seagrasses: literaturereview and mesocosm experiment. Aquatic Botany 27: 41-57.

Spivakov, B.Y., T.A. Maryutina, H. Muntau, and T. Commission Micromechanical. 1999. Phosphorus speciation in water and sediments (Technical Report). Pure and Applied Chemistry 71: 2161-2176.

Terrados, J., J. Borum, C.M. Duarte, M.D. Fortes, L. Kamp-Nielsen, N.S.R. Agawin, and W.J. Kenworthy. 1999. Nutrient and mass allocation of south-east Asian seagrasses. Aquatic Botany 63: 203-217.
Thresher, R.E., P.D. Nichols, J.S. Gunn, B.D. Bruce, and D.M. Furlani. 1992. Seagrass detritus as the basis of a coastal planktonic food chain. Limnology and Oceanography 37: 1754-1758.

Udy, J.W., and W.C. Dennison. 1997. Growth and physiological responses of three seagrass species to elevated sediment nutrients in Moreton Bay, Australia. Journal of Experimental Marine Biology and Ecology 217: 253-277.

Udy, J.W., Dennison, W.C., Lee Long, W.J., McKenzie, L.J., 1999. Responses of seagrass to nutrients in the Great Barrier Reef, Australia. Marine Ecology Progress Series, 257-271.

UN, 1997. Qatar country profile. United Nations Commission on Sustainable Development, New York.

Vizzini, S., G. Sara, M.A. Mateo, and A. Mazzola. 2003. delta C-13 and delta N-15 variability in Posidonia oceanica associated with seasonality and plant fraction. Aquatic Botany 76: 195-202.

Vonk, J.A., J.J. Middelburg, J. Stapel, and T.J. Bouma. 2008. Dissolved organic nitrogen uptake by seagrasses. Limnology and Oceanography 53: 542-548.

Wahbeh, M.I. 1988. Seasonal distribution and variation in the nutritional quality of different fractions of two seagrass species from Aqaba (Red Sea), Jordan. Aquatic Botany 32: 383-392.

Walton, M.E.M., I. Al-Maslamani, M.W. Skov, I. Al-Shaikh, I.S. AlAnsari, H.A. Kennedy, and L. Le Vay. 2014. Outwelling from arid mangrove systems is sustained by inwelling of seagrass productivity. Marine Ecology Progress Series 507: 125-137.

Yamamuro, M., and A. Chirapart. 2005. Quality of the seagrass Halophila ovalis on a Thai intertidal flat as food for the dugong. Journal of Oceanography 61: 183-186.

Yamamuro, M., H. Kayanne, and H. Yamano. 2003. delta N-15 of seagrass leaves for monitoring anthropogenic nutrient increases in coral reef ecosystems. Marine Pollution Bulletin 46: 452-458.

Yamamuro, M., Y. Umezawa, and I. Koike. 2001. Seasonality in nutrient concentrations and stable isotope ratios of Halophila ovalis growing on the intertidal flat of SW Thailand. Limnology 2: 199-205.

Yoneyama, T., T. Omata, S. Nakata, and J. Yazaki. 1991. Fractionation of nitrogen isotopes during the uptake and assimilation of ammonia by plants. Plant and Cell Physiology 32: 1211-1217.

Yu, H., Z. Yu, X. Song, X. Cao, Y. Yuan, and G. Lu. 2015. Seasonal variations in the nitrogen isotopic composition of dissolved nitrate in the Changiiang River estuary, China. Estuarine, Coastal and Shelf Science 155: 148-155. 